\title{
Contents, Vol. 11, 1990
}

\author{
No. 1-2 Editorial
}

Recent Developments concerning the Carcinoembryonic Antigen Gene Family and Their Clinical Implications. Report on the XVIIth Meeting of the International Society for Oncodevelopmental Biology and Medicine, Freiburg, FRG (September 18-22, 1989)

Zimmermann, W.; Thompson, J 1

Original Paper

Tumor Specificity of Monoclonal Antibodies to Carcinoembryonic Antigen. Immunohistochemical Analysis (With 2 color plates)

Zoubir, F.; Zeromski, J.; Sikora, J.; Szmeja, J.; Hedin, A.; Hammarström, S

Characterization of Monoclonal Antibodies Reactive with Normal Resting, Lactating and

Neoplastic Human Breast

Skilton, R.A.; Earl, H.M.; Gore, M.E.; Mcllhinney, R.A.J.; Gusterson, B.A.; Wilson, P.;

Coombes, R.C.; Neville, A.M 20

Serine Proteinase Inhibitors Produced by Human Melanoma Cell Lines

Giacomoni, D.; Najmabadi, F.; Dray, S

Mechanism of Clearance of Circulating CA19-9 in Rats

Adachi, M.; Sekine, T.; Umemoto, A.; Tsukikawa, S.; Imai, K.; Yachi, A 51

XVIIth Meeting of the International Society for Oncodevelopmental Biology and Medicine Freiburg (FRG), September 18-22, 1989 Workshop Report: Proposed Nomenclature for the Carcinoembryonic Antigen (CEA) Gene

Family

Barnett, T.; Zimmermann, W 59

Abstracts Presented by Members of the ISOBM

No. 3 Original Paper

Protein Factor of Fertility in Malignancies

Tatarinov, Y.S.; Shcherbakova, L.A.; Olefirenko, G.A.; Petrunin, D.D 113

Comparative Analysis of the Reduction of Oxaloacetate by Human Hepatoma and Normal Liver Extracts

Mazo, A.; Forner, A.; Domènech, C; Busquets, M.; Gelpí, J.L.I.; Cortes, A120

Dietary Milk Proteins Inhibit the Development of Dimethylhydrazine-Induced Malig nancy

Papenburg, R.; Bounous, G.; Fleiszer, D.; Gold, P 129

IV Contents

Oncoprecipitins from Marine Invertebrates Are Glycoproteins with a Higher Specificity to Carcinoembryonic Antigen

Pavlenko, A.F.; Kurika, A.V.; Chicalovets, I.V.; Ovodov, Y.S

Enhanced Expression and Secretion of an Epithelial Membrane Antigen (MA5) in a Human Mucinous Breast Tumor Line (BT549)

Williams, C.J.; Major, P.P.; Dion, A.S 
Radio-Immunolocalization in Nude Mice Using Anticytokeratin Monoclonal Antibodies (With 1 color plate)

Sundström, B.; Johansson, B.; Hietala, S.-O.; Stigbrand, T 158

Individualization of the Cutoff Value for Serum Squamous-Cell Carcinoma Antigen Using a Sensitive Enzyme Immunoassay

Takeshima, N.; Nakamura, K.; Takeda, O.; Morioka, H.; Tamura, H.; Takasugi, N.;

Kato, $\mathrm{H} \quad 167$

No. 4 Review

In situ Hybridization: Application to the Study of Gene Expression during Experimental

Hepatocarcinogenesis and Human Hepatocellular Carcinoma

Bernuau, D.; Feldmann, G 173

Original Paper

Immunohistochemical Analysis of Human Adenocarcinomas of the Lung Using the Mono

clonal Antibody 44-3A6

Radosevich, J.A.; Noguchi, M.; Rosen, S.T.; Shimosato, Y 181

Pre-Operative Tumour Marker Levels in Patients with Breast Cancer and Their Prognosis

van Dalen, A 189

Mast Cell Kinetics during Tumor Growth

Lauria de Cidre, L.; Sacerdote de Lustig, E 196

Increase of Epidermal Growth Factor Receptor Expression Associated with a Lack of Antiproliferative Effect of IFN- $\beta$ in Human Lung Cancer Nodules in Organotypic Culture

Martyré, M.-C; Grimaux, M.; Beaupain, R 202

Activity of Glycolytic Enzymes and Glucose-6-Phosphate Dehydrogenase in Smooth Muscle

Proliferation

Elbers, J.R.J.; Rijksen, G.; Staal, G.E.J.; van Unnik, J.A.M.; Roholl, P.J.M.; van

Oirschot, B.A.; Oosting, J 210

Datura stramonium Agglutinin-Reactive $\alpha$-Fetoprotein Isoforms in Hepatocellular Carcinoma

and Other Tumors Taketa, K; Ichikawa, E.; Yamamoto, T.; Kato, H.; Matsuura, S.; Taga, H.;

Hirai, H. 220

No. 5 Review

The Epidermal Growth Factor. A Review of Structural and Functional Relationships in the

Normal Organism and in Cancer Cells

Laurence, D.J.R.; Gusterson, B.A 229

Original Paper

Activity of Glycolytic Enzymes and Glucose-6-Phosphate Dehydrogenase in Lipoblastic and Neurogenic Proliferations

Elbers, J.R.J.; van Unnik, J.A.M.; Rijksen, G; Roholl, P.J.M.; van Oirschot, B.A.;

Staal, G.E.J 262

Contents V

Monoclonal Antibodies Reactive with the Breast Carcinoma-Associated Mucin Core Protein

Repeat Sequence Peptide Also Recognise the Ovarian Carcinoma-Associated Sebaceous Gland Antigen

Layton, G.T.; Devine, P.L.; Warren, J.A.; Birrell, G.; Xing, P.-X.; Ward, B.G.;

McKenzie, I.F.C 274

Letter to the Editor

Working Group on Tumor Marker Criteria (WGTMC) 
Bonfrer, J.M.G 287

No. 6 Original Paper

Clinical Usefulness of Prostate-Specific Antigen and Prostatic Acid Phosphatase in Patients with Prostatic Cancer

Filella, X.; Molina, R.; Jo, J.; Umbert, B.; Bedini, J.L.; Ballesta, A.M

Effect of Rat Developmental Stage at Initiation on the Expression of Biochemical Markers

during Liver Tumor Promotion

Decloître, F.; Lafarge-Frayssinet, C; Barroso, M.; Lechner, M.C.; Ouldelhkim, M.;

Frayssinet, C 295

Carcinoembryonic Antigen, Its Spatial Structure and Localization of Antigenic Determinants

Pavlenko, A.F.; Chikalovets, I.V.; Kurika, A.V.; Glasunov, V.P.; Mikhalyuk, L.V.;

Ovodov, Y.S 306

Measurement of Immunoreactive Prothrombin Precursor and Vitamin-K-Dependent

Gamma-Carboxylation in Human Hepatocellular Carcinoma Tissues: Decreased Car-

boxylation of Prothrombin Precursor as a Cause of Des-Gamma-Carboxyprothrombin

Synthesis

Ono, M.; Ohta, H.; Ohhira, M.; Sekiya, C; Namiki, M 319

Spontaneously Metastasizing Variants of a Human Lung Carcinoma Cell Line: Monoclonal Antibody Characterization

Varki, N.M.; Estes, LA.; Tseng, A.; Vu, T.P 327

Acknowledgement to the Reviewers 339

Author Index 340

Subject Index 341

Suppl. 1

Genetic Markers of Haematological Malignancy

Guest Editors: P.H. Pinkerton; M.D. Reis 